\title{
IMPLEMENTASI JARINGAN MULTIPOINT DENGAN SWITCH DALAM DUNIA PENDIDIKAN
}

\author{
Oleh \\ Agus Aan Jiwa Permana \\ Jurusan Manajemen Informatika, FTK, Undiksha
}

\begin{abstract}
ABSTRAK
Dalam perkembangan teknologi saat ini, sering ditemukan masalah dalam menghubungkan komputer stand alone (autonom) dengan komputer-komputer lainnya untuk berkoneksi dan berbagi data. Komputer-komputer dihubungkan atas dasar beberapa pemikiran-pemikiran yang sifatnya mengarah kepada beberapa hal penting seperti efektivitas, perfomance, efisiensi, dan komunikasi. Atas dasar hal tersebut, dibangunlah koneksi antar komputer. Dalam mengimplementasikan jaringan komputer ini, diperlukan beberapa perangkat untuk menghubungkannya. Salah satu perangkat yang digunakan untuk mengkoneksikan jaringan komputer adalah switch. Switch banyak digunakan dalam mengkoneksikan jaringan komputer baik dalam ruang lingkup yang kecil maupun yang relatif luas karena kemudahan yang ditawarkan dan memiliki harga yang relatif terjangkau.
\end{abstract}

Kata kunci : Komputer, Jaringan, Stand Alone, Switch.

\begin{abstract}
The current technological developments, frequently found problem in connecting the stand alone computer (autonomic) with other computers to a connection and share data. The computers are connected on the basis of some ideas that are aim to some important case such as effectiveness, Perfomance, efficiency, and communication. Therefore, it can be made the connection between computers. Implementation this computer networks, is require for connecting multiple devices. One device that can be used for connection of computers in a network is a switch. Switch are widely used in computer network connecting the well within the scope of a small and relatively broad because of the ease it offers and has a relatively reached price for users.
\end{abstract}

Keyword : Computer, Network, Stand Alone, Switch

\section{PENDAHULUAN}

Penggunaan jaringan komputer semakin meningkat setiap harinya. Hal ini dapat dilihat dari banyaknya akses jaringan yang digunakan saat ini seperti warnet, 
hotspot, maupun jaringan yang sekedar dibuat untuk kapasitas berbagi data seperti dalam sebuah kantor atau sekolah. Sehingga penting bagi kita untuk mengetahui bagaimanakah cara berkoneksi antar komputer yang membentuk sebuah jaringan. Dengan jumlah komputer yang sudah memadai, merupakan syarat cukup untuk membangun sebuah jaringan komputer yang sederhana dan dapat digunakan untuk menunjang infrastruktur dalam proses belajar mengajar khususnya untuk di dunia pendidikan. PP nomor 19 tahun 2005 tentang standar nasional pendidikan (BAB III pasal 42 point 1) menyatakan "Setiap satuan pendidikan wajib memiliki sarana yang meliputi perabot, peralatan pendidikan, media pendidikan, buku dan sumber belajar lainnya, bahan habis pakai, serta perlengkapan lain yang diperlukan untuk menunjang proses pembelajaran yang teratur dan berkelanjutan". Secara jelas disampikan oleh pemerintah bahwa sekolah harus memiliki peralatan serta media untuk melakukan aktivitas belajar dan mengajar. Dengan Bab dan pasal yang sama dengan diatas, pada point 2 dinyatakan bahwa "Setiap satuan pendidikan wajib memiliki prasarana yang meliputi lahan, ruang kelas, ruang pimpinan satuan pendidikan, ruang pendidik, ruang tata usaha, ruang perpustakaan, ruang laboratorium, ruang bengkel kerja, ruang unit produksi, ruang kantin, instalasi daya dan jasa, tempat berolahraga, tempat beribadah, tempat bermain, tempat berkreasi, dan ruang/tempat lain yang diperlukan untuk menunjang proses pembelajaran yang teratur dan berkelanjutan". Secara jelas disampaikan bahwa sekolah harus memiliki ruang labotarium.

BAB III pasal 43 point 1 "Standar keragaman jenis peralatan laboratorium ilmu pengetahuan alam (IPA), laboratorium bahasa, laboratorium komputer, dan peralatan pembelajaran lain pada satuan pendidikan dinyatakan dalam daftar yang berisi jenis minimal peralatan yang harus tersedia". Labotarium (Lab) harus minimal menyediakan peralatan yang dapat digunakan untuk pratikum oleh siswanya. Berdasarkan pengamatan yang dilakukan penulis di kota Singaraja, provinsi Bali masih banyak sekolah-sekolah yang tidak memiliki fasilitas lab yang memadai khususnya lab komputer dan jaringannya. Bagi sekolah menengah terutama yang memiliki jurusan Teknik Komputer dan Jaringan (TKJ), seharusnya wajib memeiliki sebuah lab komputer dan jaringan untuk menunjang kegiatan 
belajar bagi para siswa. Dalam membangun sebuah lab, tidak harus mengeluarkan biaya yang tinggi, karena biaya dapat diminimalisir dengan menggunakan perangkat-perangkat jaringan yang harganya relatif terjangkau untuk mengkomunikasikan komputer yang satu dengan yang lainnya. Switch adalah solusi untuk membangun sebuah jaringan dengan harga yang terjangkau untuk bidang pendidikan.

\subsection{Jaringan Komputer}

Jaringan Komputer merupakan hubungan dua atau lebih sistem komputer yang terpisah, melalui media komunikasi untuk melakukan komunikasi data satu dengan yang lain guna berbagi sumber daya/resource (anonim, 2007). Dengan menggunakan jaringan komputer, komputer-komputer akan menjadi satu kesatuan sehingga bisa saling mengakses data dan perangkat yang ada. Setelah komputer terkoneksi jaringan, akan dapat dengan mudah untuk dikoneksikan ke internet. Wahana (2008), menjelaskan bahwa jaringan komputer adalah salah satu bentuk komunikasi antar komputer, sama halnya seperti yang dilakukan oleh manusia yang dapat berkomunikasi. Kegunaan dasar dari sistem komunikasi adalah menjalankan pertukaran data antara dua pihak (Stallings, 2001). Dengan adanya jaringan, pekerjaan dapat lebih dipermudah karena dapat dikerjakan dan diakses dari segala penjuru selama masih tetap terkoneksi ke dalam sebuah jaringan. Dalam sebuah model komunikasi sederhana, terdapat beberapa elemen-elemen yang mendukung terjadinya komunikasi, antara lain : source (sumber), transmitter (pengirim), sistem transmisi, receiver (penerima), dan destination (tujuan).

Penggabungan teknologi komputer dan komunikasi sangat berpengaruh terhadap bentuk organisasi sistem komputer. Dalam sebuah institusi, keberadaan jaringan komputer sangat penting. Hal ini dapat dilihat dari adanya pusat pengolahan data dan komputasi yang biasanya dikenal dengan istilah "pusat komputer" . Pusat komputer ini mengkoordinasi komputer-komputer yang ada pada setiap fakultas atau departemen yang berjumlah banyak dan terpisah. Seperti yang dikatakan dalam 
Tanenbaum (1996) bahwa jaringan komputer adalah himpunan interkoneksi (interconnected) sejumlah komputer autonomous.

\subsection{Komunikasi Jaringan}

Dalam jaringan komputer, terdapat perangkat-perangkat (device) yang digunakan untuk membantu komunikasi. Konfigurasi Jalur adalah jumlah alat yang ada di dalam hubungan (link). Pada dasarnya terdapat beberapa jenis koneksi jaringan yang biasanya digunakan dalam melakukan komunikasi antara lain :

\section{$\checkmark \underline{\text { Point to point }}$}

Point-to-point data adalah hubungan andatar media komunikasi dengan tepat dua titik ujung dan tidak ada data atau format paket. Komputer di kedua ujung harus bertanggung jawab penuh untuk memformat data yang ditransmisikan antara mereka. Komputer di dekat dapat dihubungkan dengan kabel langsung antara kartu antarmuka (network interface card) mereka seperti yang ditunjukan pada gambar 1. Sebuah jaringan merupakan jaringan yang paling sederhana karena hanya melibatkan dua titik. Setiap titik yang terhubung ke yang lainnya dengan satu baris sambungan. Komunikasi ini salah satu jaringan paling murah dan efektif arsitektur karena tidak melibatkan biaya redundancies dan tidak menambah kompleksitas membutuhkan beberapa node berfungsi untuk membuat koneksi. Namun, jaringan ini praktis dari sudut pandang jaringan, karena jarang hanya ada satu sambungan antara dua titik yang memadai seperti pada gambar 2 . Contohnya : Komputer yang terhubung ke printer lokal dengan kabel USB.

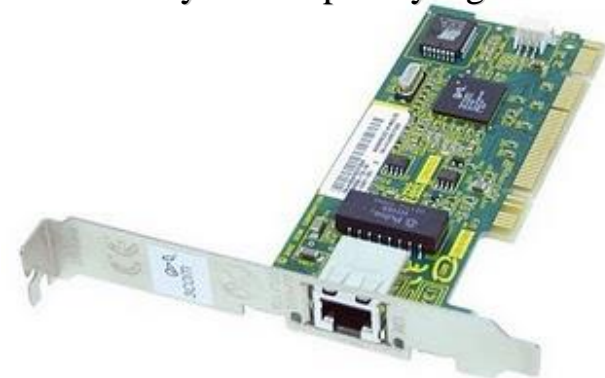

Gambar 1 : Ethernet Card/NIC (Sumber : Jiwa P., 2010)

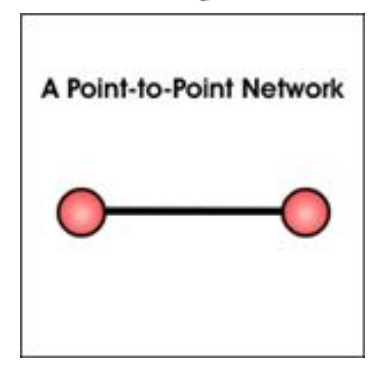

Gambar 2 : Koneksi Point to Point 


\section{$\underline{\text { Multipoint }}$}

Konfigurasi dimana terdapat lebih dari dua perangkat jaringan yang membagi jalur transmisi. Jaringan Multipoint dapat ditunjukan seperti pada gambar 3.

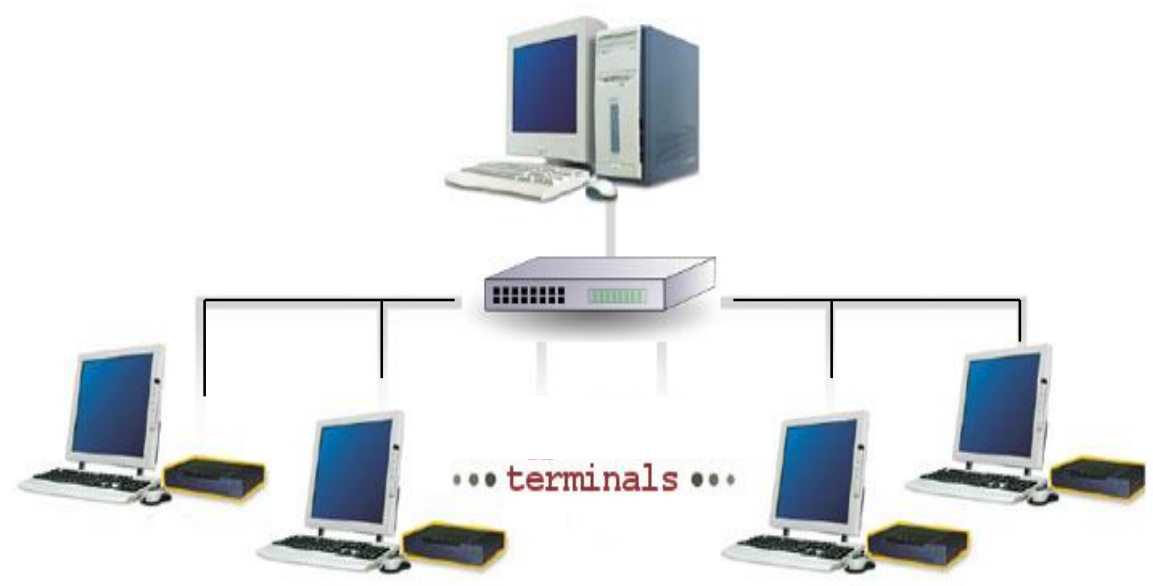

Gambar 3. Koneksi Multi Point

\section{Point to Multipoint}

Point-to-multipoint komunikasi adalah istilah yang digunakan dalam bidang telekomunikasi yang mengacu pada komunikasi yang dilakukan melalui jenis tertentu dan berbeda dari koneksi multipoint, menyediakan beberapa jalur dari satu lokasi ke beberapa lokasi. Point-to-multipoint sering disingkat dengan P2MP, PTMP, atau PMP. Sistem ini dikenal sebagai Broadband Wireless Access (BWA) atau Local Multipoint Distribution Service (LMDS), secara sejarah sama dengan sistem cellular atau narrow band wireless local loop. Sistem ini menyediakan wireless cell yang mencakup suatu area geografis yang spesifik (dengan radius sampai 4 mil) untuk men-deliver pelayanan telekomunikasi kepada pelanggan dalam area cell tersebut. Bandwidth koneksi ini dari $64 \mathrm{~kb} / \mathrm{s}$ sampai $155 \mathrm{Mb} / \mathrm{s}$.

Arsitektur ini juga menampakkan beberapa karakteristik unik yang membedakan dari jaringan public carrier yang lain. Untuk menyediakan konsistensi dan kecocokan dengan jaringan kabel, arsitekturnya didesign untuk support Asyncrounus Transfer Mode (ATM). Saat ini, ATM menawarkan 
protokol terdefini dan quality of services metrics paling bagus. ATM cell structure juga membolehkan transmisi dua arah berbagai macam media seperti voice, data dan video, dengan adaptive layering menjamin integritas medium. Adapun gambaran dari komunikasi ini dapat ditunjukan seperti pada gambar 4 .

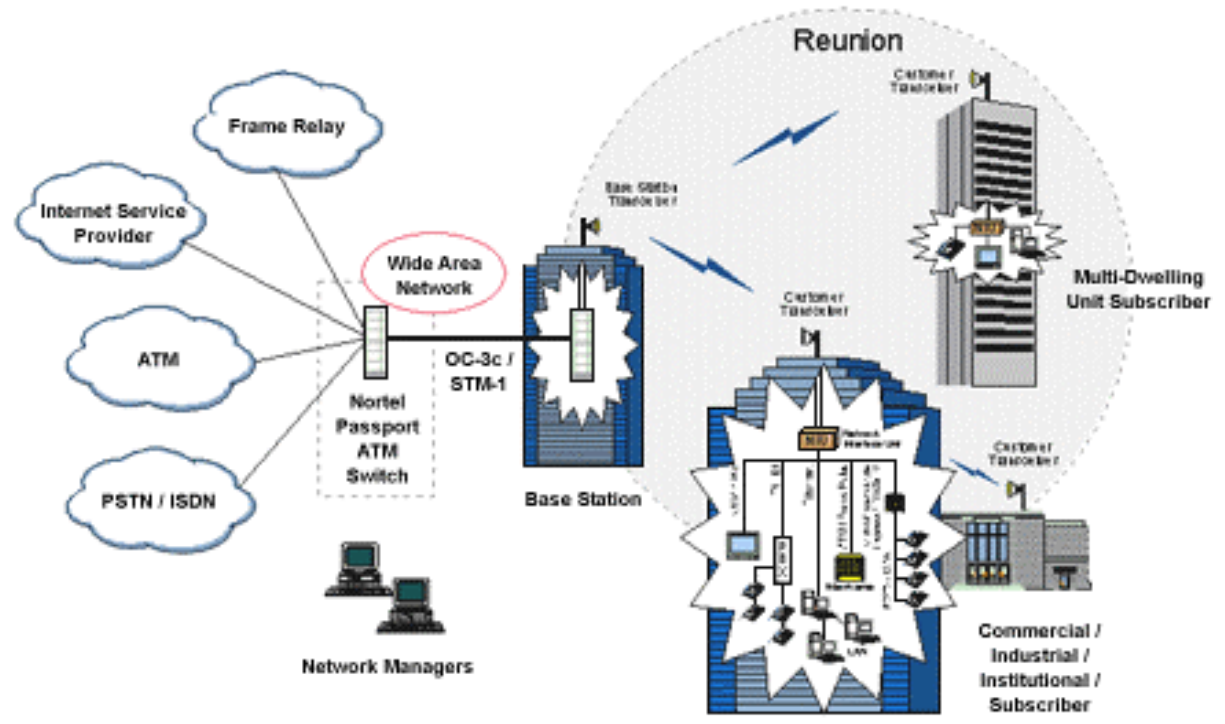

Gambar 4 : Koneksi Point to Multipoint

\section{KONFIGURASI}

\subsection{Konfigurasi UTP}

Jenis kabel yang paling banyak digunakan saat sekarang untuk kebutuhan jaringan. UTP singkatan dari unshieled twisted pair. Pertama kali kabel ini digunakan pada tahun 1881 oleh perusahaan telkom Bell. Pada awal tahun 1900 semua jaringan telepon di Amerika sudah menggunakan kabel ini. Kabel ini tidak memiliki shield/pelindung yang membuat fleksibilitasnya tinggi dan juga daya tahannya lebih kuat. Kabel UTP sudah lazim digunakan, adapun beberapa keuntungannya :

- Tipis, lebih tipis dari kabel coaxial

- Ukurannya kecil, sehingga tidak mudah memenuhi tempat pengkabelan

- Biaya murah, untuk per meternya harganya lebih murah dibandingkan dengan kabel LAN lainnya. 
- Mudah dioperasikan untuk dioperasikan dibandingkan kabel twisted pair.

Selain keuntungan, ada juga kerugian dari penggunaan kabel UTP. Kerugiannya adalah dapat diintervensi oleh gelombang elektromagnetik (lihat gambar 5)sehingga tergantung dari skema yang digunakan yang biasanya dipatenkan oleh pembuat kabelnya. Gambar kabel UTP dapat dilihat seperti pada gambar 6.

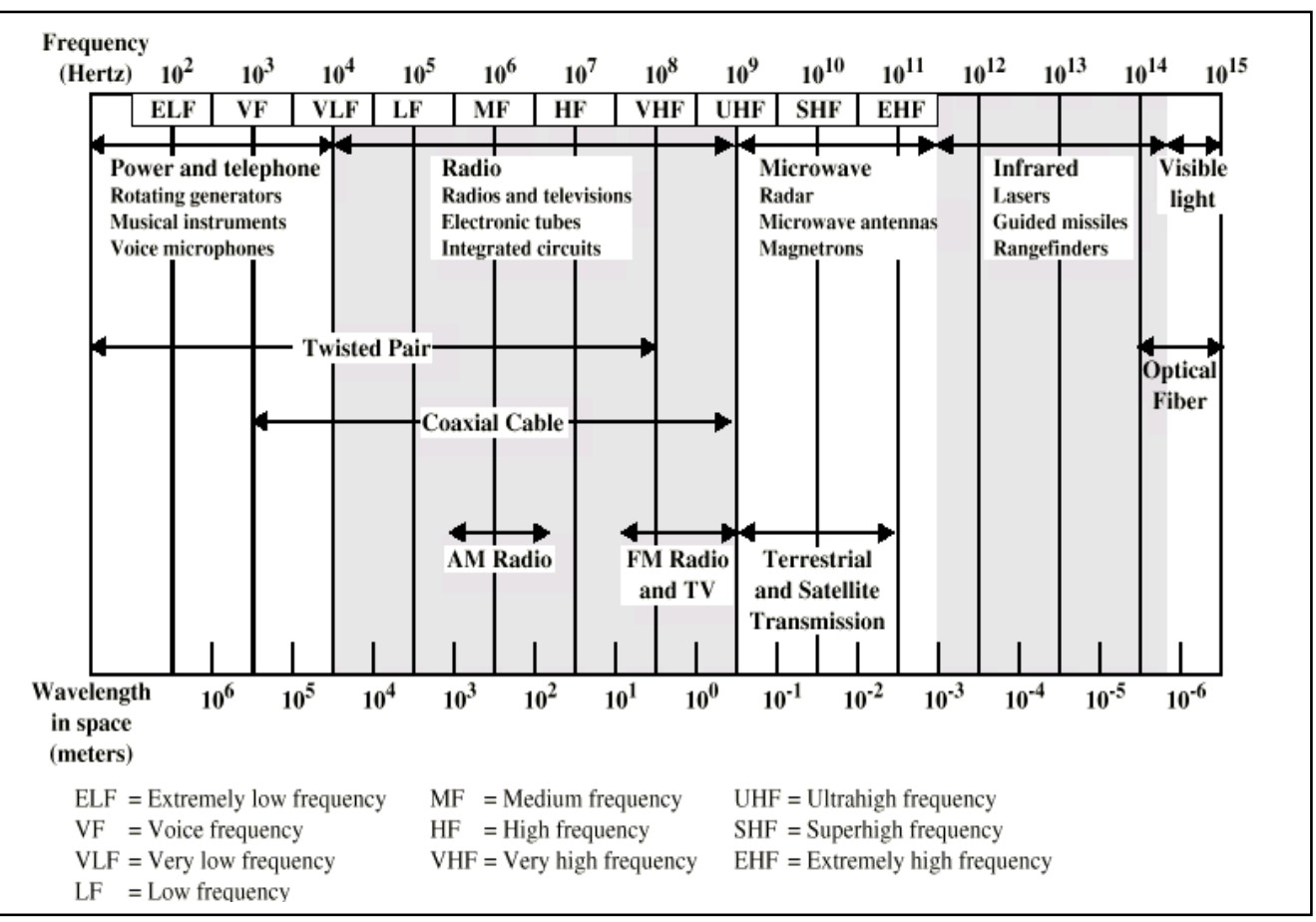

Gambar 5 : Spektrum Elektromagnetik Dalam

Komunikasi

Kabel ini memiliki dua kategori yaitu UTP 3 dan 5 yang paling banyak digunakan dalam aplikasi LAN. Kategori 3 berhubungan dengan kabel derajat suara yang suara yang sering ditemukan di sebagian besar bangunan kantor. Pada jarak yang terbatas dan desain yang tepat akan menghasilkan rate data sebesar 16Mbps. Sedangkan pada kategori 5 umum digunakan untuk pra-instalasi suatu bangunan kantor baru. Pada jarak terbatas dan desain yang tepat akan menghasilkan rate data sampai 100 Mbps. Namun perbedaan dari kedua kabel ini adalah kategori 5 jalinannya lebih rapat, harganya lebih mahal dan memiliki kinerja yang lebih baik dibandingkan dengan kategori 3. Panjang maksimal kabel UTP untuk dapat bekerja secara optimal 
adalah kurang dari 100 meter dan panjang minimal kabel UTP untuk dapat bekerja secara optimal adalah lebih dari 2 meter. Sehingga dalam pemasangan ini harus memperhatikan beberapa ketentuan, antara lain.

- Panjang kabel UTP dari Switch ke Server maksimal 8 meter

- Panjang kabel UTP dari Switch ke Workstation di ruangan server maksiman $12 \mathrm{M}$

- Panjang kabel UTP dari Switch ke Workstation di ruangan lainnya maksimal $100 \mathrm{M}$

Dalam jaringan, kabel ini biasanya dirangkai menjadi jenis straight atau crossover. Perbedaan susunan rangkaian kable dapat dilihat pada gambar 7. Ujung kabel UTP harus diisi dengan konektor yang bernama RJ-45.

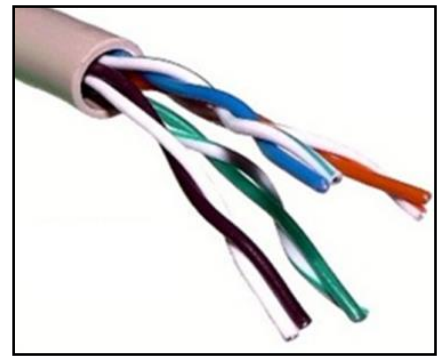

Gambar 6 : Kabel UTP

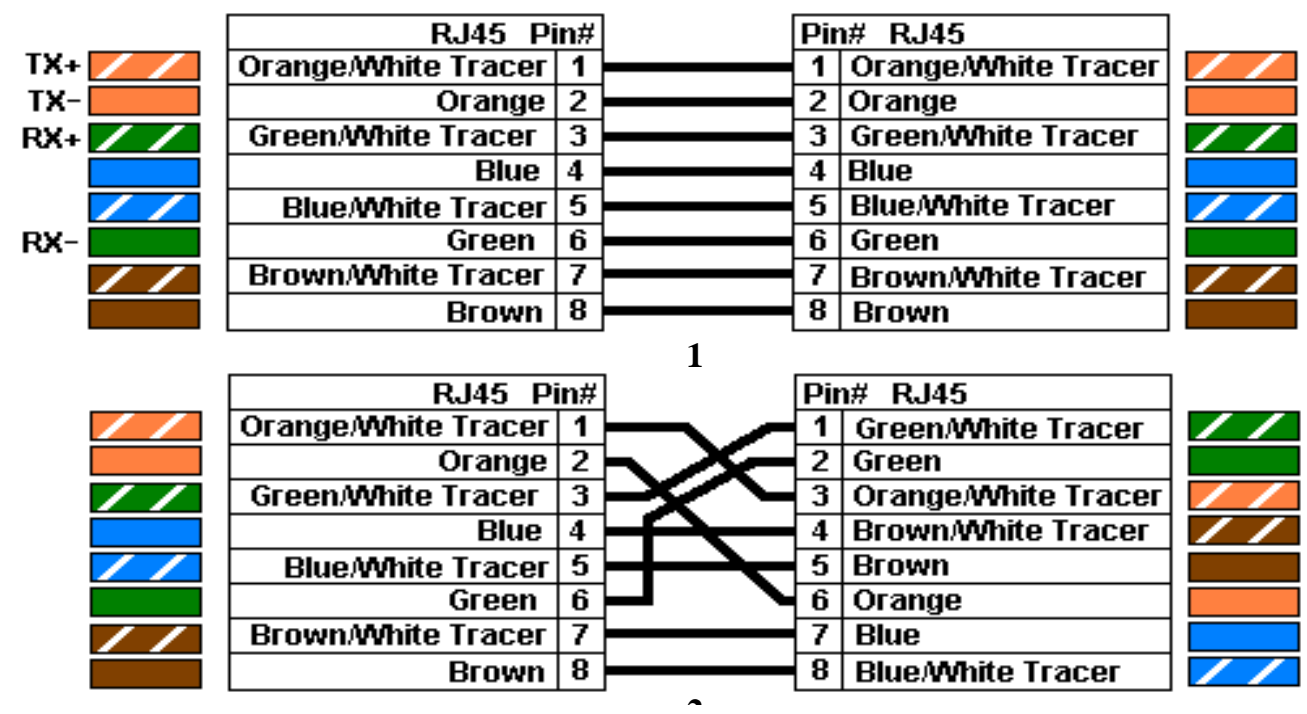

Gambar 7 : Susunan kabel UTP Straight (Atas). Cross Over (Bawah) 


\subsection{Konfigurasi Switch}

Switch adalah perangkat sederhana yang juga berfungsi untuk menghubungkan beberapa komputer. Switch memang identik dengan Hub, tetapi Switch lebih cerdas dan memiliki performa tinggi dibanding Hub. Secara tipikal berikut kelebihan dari Switch dari Hub :

- Mampu menginspeksi paket-paket data yang mereka terima

- Mampu menentukan sumber dan tujuan paket yang melaluinya

- Mampu mem-forward paket-paket dengan tepat.

Switch yang bekerja secara simultan di lebih dari satu layer sehingga dikenal dengan multilayer switch. Switch biasanya memiliki dua jenis port. Port biasa dan port uplink. Port uplink, yang merupakan sebuah port yang dapat digunakan untuk menghubungkan switch dengan yang lainnya di dalam sebuah jaringan berbasis teknologi Ethernet. Port ini ditunjukan seperti pada gambar 8. Dengan menggunakan uplink port, switch dapat disusun secara bertumpuk untuk membentuk jaringan yang lebih besar dengan menggunakan kabel UTP yang disusun secara stright. Jika switch yang digunakan tidak memiliki port uplink, maka kita dapat menggunakan kabel UTP yang disusun secara crossover.

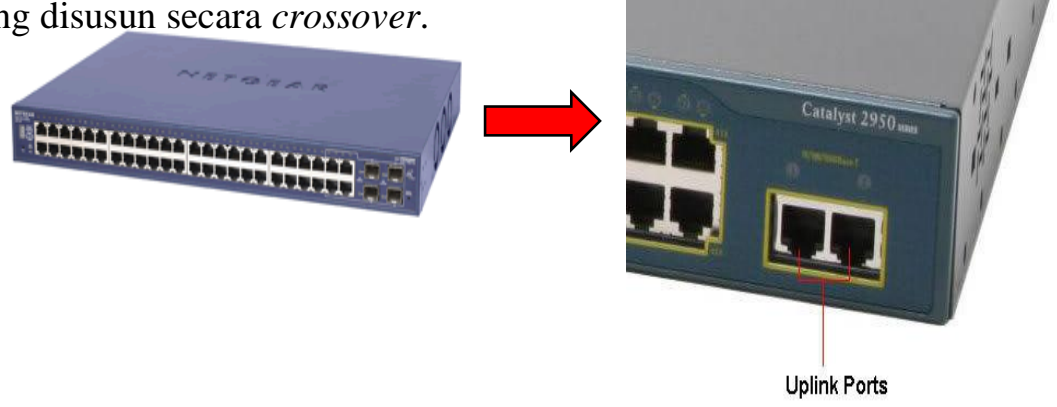

Gambar 8 : Switch dengan port uplink

Penggunaan kabel straight dan crossover yang digunakan untuk menghubungkan perangkat, tergantung dari jenis perangkat yang digunakan. Penggunaanya dapat dilihat seperti pada tabel 1. Pada dasarnya langkah yang dilakukan untuk setingan switch ini adalah sederhana. Komputer-komputer yang sudah ada dihubungkan 
menggunakan sebuah kabel jaringan yang sudah berisi RJ-45. Ujung kabel yang berisi connector di masukan ke dalam port yang ada pada switch. Selanjutnya atur IP address untuk masing-masing komputer, dan pastikan semua IP yang digunakan tidak ada yang sama. Skema koneksinya, dapat digambarkan seperti pada gambar 9 .

Tabel 1 : Penggunaan Kabel Straight dan Crossover

\begin{tabular}{|c|c|}
\hline STRAIGHT & CROSSOVER \\
\hline $\begin{array}{l}\text { - } \text { menghubungkan komputer ke port biasa } \\
\text { di Switch. } \\
\text { - menghubungkan komputer ke port LAN } \\
\text { - modem cable/DSL. } \\
\text { - menghubungkan port WAN router ke } \\
\text { port LAN modem cable/DSL. } \\
\text { - } \text { menghubungkan port LAN router ke } \\
\text { port uplink di Switch. } \\
\text { - menghubungkan } 2 \mathrm{Hub/Switch} \text { dengan } \\
\text { salah satu Hub/Switch menggunakan } \\
\text { port uplink dan yang lainnya } \\
\text { menggunakan port biasa. }\end{array}$ & $\begin{array}{l}\text { - menghubungkan } 2 \text { buah komputer } \\
\text { secara langsung } \\
\text { - menghubungkan } 2 \text { buah } \\
\text { Hub/Switch menggunakan port } \\
\text { biasa diantara kedua Hub/Switch. } \\
\text { - menghubungkan komputer ke port } \\
\text { uplink Switch } \\
\text { - menghubungkan port LAN router } \\
\text { ke port biasa di Hub/Switch }\end{array}$ \\
\hline
\end{tabular}

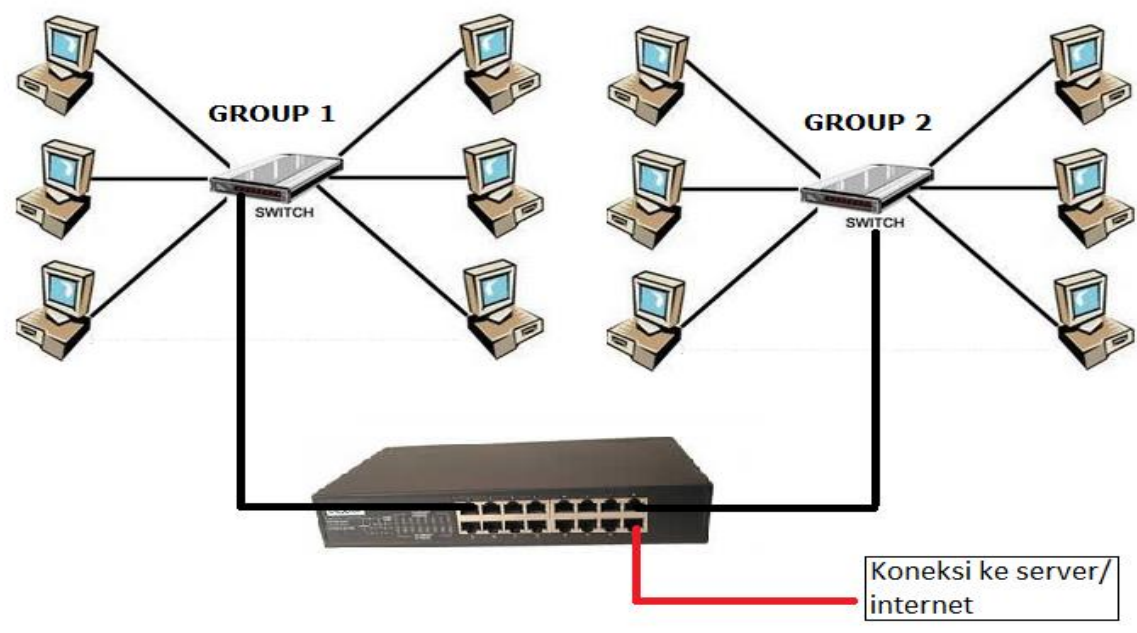

Gambar 9: Skema Multipoint dengan Switch 


\section{IMPLEMENTASI}

Dalam implementasi ini, switch yang digunakan adalah switch dengan jenis DLink. Tampilan dari switch yang digunakan dapat dilihat seperti gambar 10. Dengan menggunakan switch ini, komputer yang ada di lab jaringan, dibagi menjadi dua bagian yaitu sisi kiri (group 1) dan sisi kanan (group 2). Masing-masing komputer yang ada pada setiap group dikoneksikan dengan 1 buah switch dan settingan IP address kelas $\mathrm{C}$ dengan jumlah komputer 8 buah.

Kemudian untuk menghubungkan dua buah switch yang dibagi menjadi group 1 dan group 2 digunakan kabel dengan sususan crossover hal ini karena switch yang digunakan tidak memiliki uplink port.

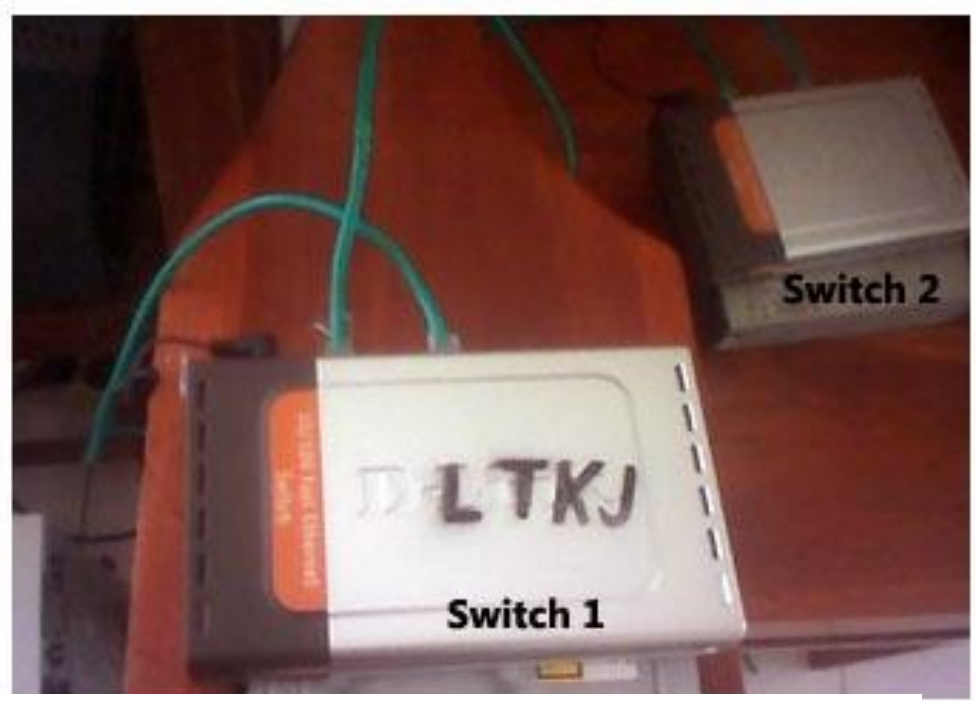

Gambar 10 : Koneksi Switch D-Link

(Sumber : Jiwa P., 2010)

\section{PENUTUP}

Koneksi multipoint yang melibatkan beberapa komputer untuk dikoneksikan dengan kabel UTP telah dapat dilakukan. Sejauh ini, percobaan koneksi yang dilakukan berjalan lancar dan sesuai dengan harapan, sehingga semua komputer yang berada dalam dua buah group dapat dikoneksikan dan berhubungan. Dengan menggunakan komponenen switch sebagai penghubung antar komputer, biaya untuk membangun suatu labotarium jaringan pada sekolah menegah umum/kejuruan diharapkan mampu untuk diminimalisir. Tidak dipandang sebagai suatu kendala 
yang sangat sulit untuk dipecahkan lagi. Demi kemajuan pendidikan di Indonesia, hal semacam ini wajib dilakukan untuk meningkatkan prestasi belajar siswa sehingga dapat bersaing di tingkat nasional maupun tingkat internasional.

\section{DAFTAR PUSTAKA}

Anonim, 2007, Modul I : Konsep Dasar Jaringan, Smk Telkom Sandhy Putra, Yayasan Sandhykara Putra Telkom, Malang

Jiwa P., A.A., 2010, Membangun Jaringan Komputer Berbasis Multipoint Dengan Memanfaatkan Switch, www.ilmukomputer.com, ( Diakses : 5 Mei 2011)

Peraturan Pemerintah Republik Indonesia Nomor 19 Tahun 2005 Tentang Standar Nasional Pendidikan, www.hukumonline.com, (Diakses : 5 Mei 2011)

Stallings, W., 2001, Komunikasi Data dan Komputer : Dasar-Dasar Komunikasi Data, Edisi Pertama, Diterjemahkan oleh : Thamir Abdul Al-Hamdany, B.Sc., M.Sc., Salemba Teknika : Jakarta

Tanenbaum, A. S., 1996, Jaringan Komputer, Edisi III, diterjemahkan oleh : (Purnomo W. I., Endang S., A. A. Putri Ratna), Prenhallindo : Jakarta

Wahana, 2008, Administrasi Jaringan Menggunakan Linux Ubuntu 7, ANDI : Yogyakarta 